\title{
DETERMINATION OF LEVELS OF LEAD AND CADMIUM CONTAMINATION IN MEAT PRODUCTS SOLD IN NORTHERN LEBANESE MARKETS
}

\author{
P.J. OBEID, C.E. SALIBA, M. YOUNIS, S. AOUAD \& J. EL-NAKAT \\ Department of Chemistry, University of Balamand, Lebanon.
}

\begin{abstract}
The levels of lead and cadmium have been determined in canned and processed meat products sold in North Lebanon. Such products are normally available all year round in the markets. Never before have these meat products been assessed for their levels of toxic metals nor have they been given the deserved attention regarding their impact on human health. Using closed-vessel microwave acid-assisted digestion and graphite furnace atomic absorption spectroscopy, the levels of lead $(\mathrm{Pb})$ and cadmium $(\mathrm{Cd})$ were determined in 75 brands of canned and 33 brands of processed (cold cuts) meat sold in the northern part of the country. The data provided extremely important information to whether or not Lebanese individuals are exposed to high levels of such toxic metals where specifically children were found to be more vulnerable to such exposures. In canned meat, the data showed that the levels of $\mathrm{Pb}$ ranged from 0.00020 to $0.8161 \mu \mathrm{g} / \mathrm{g}$ with a mean of $0.02696 \mu \mathrm{g} / \mathrm{g}$, while 29 brands were below the detectable limit. As for Cd, the data revealed levels ranging from 0.00019 to $0.1382 \mu \mathrm{g} / \mathrm{g}$ with a mean of $0.01557 \mu \mathrm{g} / \mathrm{g}$, while seven brands were below the detectable limit. In processed meat samples, $\mathrm{Pb}$ concentrations ranged from 0.00025 to $0.06135 \mu \mathrm{g} / \mathrm{g}$ with a mean of $0.0174 \mu \mathrm{g} / \mathrm{g}$ of which three brands showed nondetectable levels. Concentrations of cadmium ranged from 0.0000245 to $0.0071 \mu \mathrm{g} / \mathrm{g}$ where the mean concentration was found to be $0.002386 \mu \mathrm{g} / \mathrm{g}$. Two major parameters, amount consumed and body weight, were found to play an important role in determining whether the provisional Tolerable Weekly Intake levels (PTWIs) of $\mathrm{Pb}$ and $\mathrm{Cd}$ were exceeded or not. Specifically for canned meats, certain samples have shown that the PTWI has been markedly exceeded in children for both metals.
\end{abstract}

Keywords: Cadmium, canned meat, GFAAS, heavy metals, lead, Lebanon, microwave digestion, processed meat.

\section{INTRODUCTION}

Heavy metals are naturally occurring elements in the earth's crust [1]. Such metals were used thousands of years ago for several applications, but their concentration in the environment increased since the development of both agricultural and industrial fields [2,3]. Despite their known toxicity, heavy metals are still widely used nowadays. Moreover, they are transferred into the environment through anthropogenic activities such as mining, industrial processing, waste water irrigation, agricultural activities [4], transport and fuel combustion [2], iron and steel production, coal and oil combustion, waste incineration, non-ferrous manufacturing, and cement kilns [5].

Heavy metals find their way into living organisms from dietary and non-dietary exposure, where they accumulate and persist for long time periods, thus causing various health effects [6,7]. Accumulation depends on the organ of interest and on the metal's characteristics. The uptake of heavy metals by living organisms is related to the bioavailability of such elements, represented by the characteristics of the metal, the nutritional facts, and the age of the organism [5].

Lead is a naturally occurring contaminant that can be found in rock and soil [8]. For example, $\mathrm{Pb}$ was used for building materials, water transportation and wine sweetening, while other metals were used widely as pigments in artists' materials as well as other applications [2]. 
In addition, human activities contributed a great share in increasing its amount. Measures have been taken to reduce lead emission in the environment like banning or reducing the use of leaded-gasoline, phasing-out lead from household paint and solder-sealed canned food processing industry [9]. Lead may find its way into the food chain through several pathways, which may include direct deposition from air to edible plants, meat products from livestock, which have been exposed to contaminated plants, water, and air [10].

Ingested lead is transported primarily by the blood to the soft tissues. The concentration in both blood and soft tissues is relatively lower (1\% and $8 \%$, respectively, of absorbed lead) [11] than its concentration in bones (up to $90 \%$ accumulation in bones). Possessing several similarities, lead can be mistaken for calcium. Thus, bones are considered to be a long-term storage reservoir for lead, a fact that is apparent from the half-life of lead in blood and soft tissues (approximately 30 days) in comparison to its half-life in bones, which ranges from 10 to 30 years from which $\mathrm{Pb}$ is released slowly overtime. Pregnancy leads to an increase in blood lead concentration for the mother caused by the release of lead from maternal bones when the calcium is mobilized to construct the fetal skeleton [9]. In addition, maternal lead is transferred to the fetus through the placenta, and later during breast feeding. The most important targets for lead toxicity in humans are the blood, nervous, and cardiovascular systems, as well as the kidneys [12]. The International Agency for Research on Cancer (IARC) has classified lead as a class 2A carcinogen [8]. For adults, lead is associated with neurological toxicity that was found to influence the central information processing mainly leading to visiospatial organization disorder and affects short-term verbal memory. It also causes psychiatric symptoms and manual agility impairment [8]. Besides neurological toxicity, lead may cause other health problems such as delayed sexual maturation, affects the reproduction by decreasing the number and quality of sperm and by increasing the frequency of abortions, developmental delays, hypertension caused by reduction of nitric oxide (NO) concentration in blood, impaired hemoglobin synthesis, tiredness, sleeplessness, anemia, irritability, osteoarthritis, headaches, constipation, weight loss, joint pain, and muscle weakness [8]. According to the United States Food and Drug Administration (FDA), provisional total tolerable daily intake levels (PTTILs) of $\mathrm{Pb}$ are set at $0.025 \mu \mathrm{g} / \mathrm{g} /$ day for pregnant women, while for infants, it was set at $0.006 \mu \mathrm{g} / \mathrm{g} /$ day [13]. Meanwhile, the Joint Food and Agricultural Organization (FAO) and the World Health Organization (WHO) Expert Committee on Food Additives (JECFA) have set the provisional tolerable weekly intake (PTWI) of lead at $0.025 \mu \mathrm{g} / \mathrm{g}$ body weight (bw) for all age groups [13].

Such differences in standard levels arise first from the FDA's recommendations in being extremely cautious, while the World Health Organization argues that our bodies will metabolize and excrete lead efficiently as long as the amount of lead that we are exposed to does not exceed its PTWI [14]. For this reason, the JECFA safe levels are more widely accepted by scientists.

Cadmium (Cd), on the other hand, is a naturally occurring, relatively volatile, slivery-white soft metal with two valence states. It is classified as non-essential toxic metal having the ability to bioaccumulate in living organisms and is not easily excreted [10]. Cadmium plays a significant role in various anthropogenic applications, where it is mixed with other metals (copper, silver, tin and lead) to form metallic alloys [15]. Cd finds its application mostly in nickel/ cadmium batteries, plastics stabilizers and pigments, electronic compounds, and is used as a protective coating to prevent the corrosion of other metals. Cadmium can also be found as an impurity in phosphate fertilizers, detergents and petroleum products [10]. Sources of human exposure to cadmium may be attributed to industry, air, soil, and water, which all pose an exposure risk to animals, their products as well as other food commodities $[8,10,11,16,17]$. 
Human exposure to cadmium occurs through inhalation, dermal contact, but to a greater extent through ingestion. Due to the fast uptake of cadmium by leafy vegetables and crops from contaminated soil, cadmium can be readily transferred to animals grazing on such contaminated plants, whereby it accumulates mainly in their tissues [18]. This leads to its presence in the food-chain, thus making meat and offal an important route of exposure to cadmium [19]. Absorption depends on the solubility of cadmium in the ingested compounds and also on the nutritional status of the organism where iron and calcium deficiency leads to higher cadmium absorption [20]. Possessing great similarities to zinc, a bio-essential nutrient for living organisms, $\mathrm{Cd}$ has the ability to displace zinc in important enzymatic and organ functions leading to the impairment or induction of such tasks. The kidney and liver are considered as target organs for cadmium accumulation although the liver is less sensitive to cadmium than the kidneys [21]. The half-life of Cd may range from 6 to 38 years depending on the organ in which they accumulate (6-38 years in human kidney and 4-19 years in human liver) [10]. Chronic exposure may lead to renal failure, presence of serum proteins in urine, osteomalacia, osteoporosis, lung dysfunction leading to lung disease, and bone damage, while acute exposure may lead to headache, vomiting, diarrhea, reduced body weight, ulcers, hemorrhages, testicular weakening, reddening of intestinal track and stomach [21], chest pain, muscle weakness, pulmonary edema, bronchitis, respiratory failure, renal failure, affects also the liver, cardiovascular system, and nervous system [20]. According to a study on the effects of cadmium on kidney cells, cadmium was found to induce changes in the cells related to the proliferation of pre-neoplastic cells, possibly leading to cadmium-induced carcinogenicity [21]. According to the JECFA, a PTWI of cadmium is calculated on the assumption that $5 \%$ of all the dietary cadmium is absorbed and is proposed to be applied to long-term consumption. This PTWI is established to be $0.007 \mu \mathrm{g} / \mathrm{g}$ bw for cadmium per week [21]. The U.S. Environmental Protection Agency (EPA) established a reference dose of food intake of cadmium of $0.001 \mu \mathrm{g} / \mathrm{g}$ bw/day, and the limit of intake of cadmium through drinking water of $0.0005 \mu \mathrm{g} / \mathrm{g}$ bw/day. Such difference of intake of reference doses between food and water is due to the difference in the levels of absorption of cadmium [8].

As mentioned, there are many routes for human exposure to lead and cadmium. Individuals should be aware of the health effects resulting from the consumption of heavy metal contaminated food products. While the food chain constitutes a main source of accumulation of such heavy metals, meat products represent an essential part of the human diet and are consumed mostly on daily basis. This makes them a continuous source of exposure to lead and cadmium, thus leading to various diseases linked to the toxicity of such metals. Accordingly, it is important to determine their levels in meat and meat products to assess the health risks derived from their consumption. The level of heavy metals in meat and meat products depend on several factors such as the environmental conditions, grazing land, and the genetic characteristics of the animal's organism [22].

A recent study carried out in the central Bekaa plain of Lebanon [18] has revealed that soil metal contamination was mostly due to the use of contaminated water, to compensate for water shortage and to the heavy use of fertilizers. Such conditions can negatively affect animals that feed on plants grown in such lands, whereby consumption of animal meat products can also expose humans to such toxic metals. A more related study [23] was carried out to assess the impact of metal cans on food quality. However, the study does not comprehensively cover all canned meat products, nor it included any of the processed kind (cold cuts) and focuses mainly on metal contents of cans and its effects. Since there are no food safety programs in Lebanon that monitor consistently the quality of all food products, whether imported or local, and since very little research information exists on toxic metal contamination 
in processed and canned meat, the objective of this work is to determine the contamination level of lead and cadmium in as many of such products available to the consumer, compare them with safe standard levels, and to also create awareness and perhaps ignite the interest of private or governmental sectors to become seriously engaged in such studies, all for the safety and development of better food quality.

\section{MATERIALS AND METHODS}

\subsection{Apparatus}

Prior to digestion, samples were dried overnight in a programmable oven (Venticell, W.P.Katul). Samples were digested using Thermo Ethos 1 microwave digestion oven (Milestone, Italy). For metal analysis, a Thermo-Electron $M$ series graphite furnace atomic absorption spectrometer (GFAAS) equipped with deuterium and Zeeman background correction (Zeeman Furnace GF95Z) and an autosampler (FS95) were used (Thermo Electron Corporation, Germany). The sample atomization is carried out in specialized graphite tubes (Thermo Elemental Omega Platfrom Extended Lifetime Cuvettes). Coded hollow cathode lamps for lead and cadmium (Thermo-electron Corporation, Germany) were also used. 99.999\% pure argon gas (Chehab Industrial and Medical Gases S.A.L., Lebanon) was used as an internal inert gas for the GFAAS with a flow rate of $300 \mathrm{~mL} / \mathrm{min}[1,3]$.

\subsection{Reagents}

Throughout the digestion and detection procedures, double distilled de-ionized Water $\left(\mathrm{ddH}_{2} \mathrm{O}\right)$ obtained by water treatment using Milli-Q system (Millipore) was used. Working standards for lead and cadmium were prepared using standard solutions supplied by RomilPure chemistry (standard solutions of $1000 \mathrm{ppm}$ element reference solution). Ultrapure concentrated nitric acid $(65 \%)$ was used for the sample digestion as well as for the preparation of wash solution $(1 \%, \mathrm{v} / \mathrm{v})$ and diluents $(0.5 \%$, v/v) for the GFAAS [1,3]. Ascorbic acid (99.99\% pure, trace metal basis, Sigma-Aldrich) was used as the matrix modifier for lead detection, while magnesium nitrate $(99.99 \%$ pure, trace metal basis, Sigma-Aldrich) was used as the matrix modifier for cadmium detection in the GFAAS. Certified reference material (CRM) (SRM1577C Bovine Liver NIST National Institute of Standards and Technology, USA) was used in part for quality control and validation of all analytical procedures throughout.

\subsection{Optimization conditions}

Both cadmium and lead are volatile elements in nature with a wide range of volatility that is dependent on the amount of heat applied. Thus, caution should be taken into consideration for choosing the optimum conditions for the heating program of the GFAAS and whether or not modifiers should be used.

\subsubsection{Lead and cadmium optimization}

The atomization temperature for $\mathrm{Pb}$ was very critical especially in the range of $1400-1600^{\circ} \mathrm{C}$. Nevertheless, the type of matrix modifier also plays an important role when using complex samples. Upon careful optimization, the optimum atomization temperature was found to be best at $1400^{\circ} \mathrm{C}$ while the best matrix modifier was found to be $1 \%$ ascorbic acid. As for Cd, 
it was shown that the ashing temperature was of importance where an increase in the ashing temperature revealed a decrease in the absorbance signal and vice versa. This pattern was observed in the presence and absence of matrix modifiers. Optimum results were obtained by using an ashing temperature of $350^{\circ} \mathrm{C}$ and a $2000 \mathrm{ppm}$ solution of $99.99 \%$ pure and trace metal basis $\mathrm{Mg}\left(\mathrm{NO}_{3}\right)_{2} \cdot 6 \mathrm{H}_{2} \mathrm{O}$ as the matrix modifier.

\subsection{Materials}

All plastic and glass-wares were washed with soap and tap water, rinsed with $\operatorname{ddH}_{2} \mathrm{O}$, and then soaked overnight in $10 \%$ (v/v) nitric acid solution [1,24,25]. Prior to usage, any item was washed three times with $\mathrm{ddH}_{2} \mathrm{O}$. Acid-digested samples were stored in 50-mL polypropylene conical tubes (LaboTech, Lebanon), which were soaked in 10\% nitric acid solution and washed with $\mathrm{ddH}_{2} \mathrm{O}$ prior to use. Reagents and sample cups (LaboTech, Lebanon) for the autosampler of the GFAAS were also soaked and washed thoroughly with $\mathrm{ddH}_{2} \mathrm{O}$ before filling them with the samples to be analyzed.

\subsection{Samples and treatment}

Samples of canned and processed meat (cold cuts) were purchased from various supermarkets in North Lebanon. Seventy-five different brands of canned meat and 33 of processed that can be usually found all year long in markets were considered for this study. All canned meat samples were classified under five categories namely chicken $(\mathrm{Ch})$, beef $(\mathrm{B})$, pork $(\mathrm{P})$, duck (D), and mixed (M, mixed beef/pork/herbs and/or olives). Similarly, the processed which included cold cuts such as mortadella, ham, salami, pepperoni, and such, were characterized under turkey $(\mathrm{T})$, pork $(\mathrm{P})$, mixed chicken and turkey $(\mathrm{C}+\mathrm{T})$, mixed beef and chicken $(\mathrm{B}+\mathrm{C})$, mixed pork and beef $(\mathrm{P}+\mathrm{B})$, and mixed pork and chicken $(\mathrm{P}+\mathrm{C})$. For all samples studied, whether canned or processed, and in order to get a representative sample, a few grams of tissues were taken from separate subsamples of the same brand, pooled together, homogenized by cutting into fine pieces by using pre-soaked disposable plastic knives, placed in small pre-soaked Petri dishes, then dried at $70^{\circ} \mathrm{C}$ overnight until a constant sample weight is obtained $[1,24,26]$. Dried samples were then stored in tightly sealed acid-treated storage $50-\mathrm{mL}$ conical tubes for later use. A quantity of $0.5 \mathrm{~g}$ of each dried sample was transferred to a high temperature high-pressure Teflon reaction vessel specific for Ethos 1 microwave oven, followed by the addition of $7 \mathrm{~mL}$ of ultrapure concentrated nitric acid $(65 \%)$ and $1 \mathrm{~mL}$ of $30 \%$ concentrated pure hydrogen peroxide $[1,24,27]$. Similarly, and for quality control purposes, $0.5 \mathrm{~g}$ of the CRM was also included in each batch and treated in the same manner as any other sample. All samples, as well as CRMs, were run in triplicates. As for the control blanks (two in each batch), the vessels contained $7 \mathrm{~mL}$ acid and $1 \mathrm{~mL} \mathrm{H}_{2} \mathrm{O}_{2}$, except where the

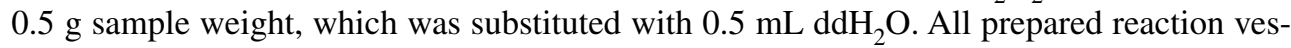
sels were left under a fume extraction hood for at least $15 \mathrm{~min}$ to allow the formed gases to escape. The vessels were then sealed and placed inside the microwave oven and digested using a three-step program. During the first step, samples were heated from room temperature to $200^{\circ} \mathrm{C}$ in $30 \mathrm{~min}$ at $1000 \mathrm{~W}$. The second step consisted of maintaining the samples at $200^{\circ} \mathrm{C}$ for $30 \mathrm{~min}$ at $1000^{\circ}$. In the final step, samples were brought to room temperature. The clear digested samples were transferred into $25-\mathrm{mL}$ volumetric flasks and diluted with $\mathrm{ddH}_{2} \mathrm{O}$ up to the mark prior to their transfer to $50 \mathrm{~mL}$ pre-soaked pre-cleaned polypropylene tubes and were finally stored in the refrigerator before analysis with GFAAS $[1,3]$. 


\subsection{Sample analysis by GFAAS}

Before analyzing the samples in the GFAAS, the instrument was programmed according to the type of analyte to be detected. Following metal selection, the optimized parameters of the specific metal were set in the software of the instrument. Calibration standards for $\mathrm{Pb}$ and $\mathrm{Cd}$ were carefully prepared by diluting a certain amount taken from their stock solutions (1000 $\mathrm{ppm}$ ) down to $10 \mathrm{ppb}$ (mother solution) for lead, and similarly to $1 \mathrm{ppb}$ (mother solution) for cadmium, by using subsequent 10 -fold dilutions each time so as to diminish the analytical preparation errors as much as possible. The mother solutions were used by the GFAAS's auto-sampler to create automatically a specified calibration curve specific for each metal. The number of calibration points was automatically set by the instrument and included five points for each metal. $0.5 \%(\mathrm{v} / \mathrm{v})$ nitric acid solution was prepared for the auto-sampler for use as diluent, while $1 \%(\mathrm{v} / \mathrm{v})$ nitric acid solution was prepared and used by the auto-sampler to wash the injection tube between each dilution, as well as the samples to be analyzed, so as to prevent any cross-over contamination between any of them $[1,3]$.

From each digested sample, as well as digested CRMs, $1 \mathrm{~mL}$ aliquots were taken and were placed in a 1-mL pre-cleaned polypropylene GFAAS sample cups, which were loaded onto the autosampler of the GFAAS. As well, standard mother solutions, diluents, and matrix modifiers were placed in $20-\mathrm{mL}$ pre-cleaned polypropylene reagent cups and were also loaded onto the auto-sampler. Considering the amount of time that the GFAAS needs to analyze each sample, up to 30 samples were included in each run per each working day. All specimens were run in batches with digested blanks and CRMs. Digestion blanks were used to test for the presence of any possible contamination in the digestion procedure, while CRMs were included to calculate the recovery of the digestion process $[1,3,24]$.

For further quality control, the instrument was programmed to periodically re-measure sample blanks and standards from the calibration curve after every 10 samples to check for any instrumental variations during the analysis, thus ensuring fidelity and consistency of the data.

\section{RESULTS AND DISCUSSION}

The aim of this work was to first collect and analyze all possible meat brands normally sold in Lebanese markets for their contents of $\mathrm{Pb}$ and $\mathrm{Cd}$. Second was to compare contamination levels with standard values set by health organizations. Third, and most important, was to make the general population, aware of the health hazards that may arise from consuming such products that may potentially ignite the interest of private and governmental health organizations to engage in such studies. For this purpose, the contents of lead and cadmium in 75 brands of canned and 33 brands of processed meat found in the Lebanese markets were determined.

As in all analytical procedures, quality control (QC) is a necessary and a crucial part. The accuracy and precision of the microwave digestion oven and the GFAAS as well as the methods used have all been examined using CRM, blank samples, and replicates within every batch. The recovery percentages of the digested CRMs were all found to fall within the accepted analytical range of $80-120 \%$, thus confirming the validity of the analytical procedure and the authenticity of the results. All digested blanks and prepared standards passed the QC checks set by the software. The calibration curves showed excellent linearity, with $R^{2}$ values ranging between 0.9954 and 0.9998 , thus demonstrating the excellent performance of the instrument over the broad range of concentrations used. 
In general, results from the analyzed samples have shown wide variations of $\mathrm{Pb}$ and $\mathrm{Cd}$ concentrations (Table 1). Concentrations were based on dried weight ( $\mu$ g of metal/g of dried sample) so as to eliminate the water content differences between all samples $[1,24,26]$. The numbers of brands in each category, their minimum, maximum, mean detectable concentrations, as well as the number of non-detectable samples, have all been summarized in Table 1.

Forty-six samples (61\% of analyzed brands) of the canned meat were found to exhibit various levels of $\mathrm{Pb}$ contamination, while 68 samples $(91 \%)$ showed $\mathrm{Cd}$ contamination. For the processed meat, $91 \%$ exhibited various $\mathrm{Pb}$ concentrations, while $94 \%$ revealed the presence of $\mathrm{Cd}$. According to the EU directive 466/2001 [3], which regulates the amounts of $\mathrm{Pb}$ and $\mathrm{Cd}$ in meat and their products, the maximum allowed levels (MAL) of $\mathrm{Pb}$ and $\mathrm{Cd}$ in meat and meat products were set at 0.100 and $0.050 \mu \mathrm{g} / \mathrm{g}$, respectively. This study has shown that certain sample brands have markedly exceeded such levels.

The data also showed that the concentrations of the studied metals are generally much higher in canned meat in comparison to processed ones and that there was no correlation between the concentrations of both metals. The data also showed non-detectable levels for both metals in canned and processed meat. This suggested that toxic metal contamination was not due to a known constant factor (processing and canning) but rather due to many other factors, which may be attributed to the source of meat (i.e. type, origin, and diet of the corresponding animal). When the highest concentrations of $\mathrm{Pb}$ and $\mathrm{Cd}$ in canned and processed meat have been compared, the data showed that the canned meat contained 13.3 times more $\mathrm{Pb}$ than in the processed meat, meanwhile canned meats contained 19.4 times more $\mathrm{Cd}$ than in the processed ones. This difference may be attributed to bioaccumulation either from the environment or during the feeding period before slaughter or even from the leaching of the

Table 1: Data summary of lead and cadmium concentrations (in $\mu \mathrm{g} / \mathrm{g}$ ) analyzed in canned and processed meat products.

\begin{tabular}{|c|c|c|c|c|c|c|c|c|c|}
\hline & & \multicolumn{5}{|c|}{ Canned meat } & \multicolumn{3}{|c|}{ Processed meat } \\
\hline & & Beef & Chicken & Duck & Mixed & Pork & Mixed & Pork & Turkey \\
\hline \multirow{5}{*}{ ت્ّ } & Number of brands & 25 & 22 & 2 & 12 & 14 & 8 & 18 & 7 \\
\hline & $\begin{array}{l}\text { Number of non- } \\
\text { detectable brands }\end{array}$ & 10 & 9 & 2 & 3 & 5 & 1 & 1 & 1 \\
\hline & $\begin{array}{l}\text { Mean detectable } \\
\text { value }(\mu \mathrm{g} / \mathrm{g})\end{array}$ & 0.00976 & 0.05080 & - & 0.01270 & 0.03980 & 0.01852 & 0.02030 & 0.01440 \\
\hline & $\begin{array}{l}\text { Minimum detectable } \\
\text { value }(\mu \mathrm{g} / \mathrm{g})\end{array}$ & 0.00030 & 0.00140 & - & 0.00020 & 0.00120 & 0.00777 & 0.00024 & 0.00347 \\
\hline & $\begin{array}{l}\text { Maximum detectable } \\
\text { value }(\mu \mathrm{g} / \mathrm{g})\end{array}$ & 0.06040 & 0.81610 & - & 0.03670 & 0.41390 & 0.05430 & 0.06300 & 0.02660 \\
\hline \multirow{5}{*}{ 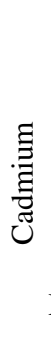 } & Number of brands & 25 & 22 & 2 & 14 & 12 & 8 & 18 & 7 \\
\hline & $\begin{array}{l}\text { Number of non- } \\
\text { detectable brands }\end{array}$ & 3 & 1 & 1 & 2 & 0 & 0 & 2 & 0 \\
\hline & $\begin{array}{l}\text { Mean detectable } \\
\quad \text { value }(\mu \mathrm{g} / \mathrm{g})\end{array}$ & 0.01570 & 0.01290 & 0.00524 & 0.02140 & 0.01390 & 0.00302 & 0.00161 & 0.00340 \\
\hline & $\begin{array}{l}\text { Minimum detectable } \\
\text { value }(\mu \mathrm{g} / \mathrm{g})\end{array}$ & 0.00010 & 0.00068 & - & 0.00040 & 0.00476 & 0.00026 & 0.00002 & 0.00118 \\
\hline & $\begin{array}{l}\text { Maximum detectable } \\
\text { value }(\mu \mathrm{g} / \mathrm{g})\end{array}$ & 0.08930 & 0.05580 & 0.00524 & 0.13800 & 0.03270 & 0.00497 & 0.00630 & 0.00716 \\
\hline
\end{tabular}


metals from the can itself [28], all of which are difficult to assess. Based on the above, processed meat products might seem to be a better choice for consumption; however, this one time study is not conclusive. Therefore, constant monitoring, to include every stage of the preparation process is a must and awareness campaigns to ensure quality are more than necessary. A number of recent studies have been conducted on fresh meat products and similar results were obtained suggesting that individuals may suffer health risks due to consumption of such products [29-31]. In the first study [29], fresh samples of chicken and beef showed to contain concentration of lead and cadmium which have exceeded the allowable levels. The second study [30] targeted the assessment of lead and cadmium levels in different types of fresh tissues from chicken where in some cases the levels suggested that individuals may be at risk from ingesting such products. Another report [31] presented the determination of lead and cadmium levels in Luncheon meet where levels of such metals were found to be a possible health hazard. Such observations are coherent with our results, which also suggest that individuals may be at risk from consuming such products.

The analyzed levels of lead in the canned meat samples have been presented in Fig. 1. The samples were grouped in categories according to the type of meat studied and in increasing order of concentrations detected within and between each category. Following the figure from left to right; $\mathrm{Pb}$ levels in duck samples have been found to be non-detectable (nd), while they varied from nd to $0.0367 \mu \mathrm{g} / \mathrm{g}$ in the mixed, nd to $0.0604 \mu \mathrm{g} / \mathrm{g}$ in beef, nd to $0.4139 \mu \mathrm{g} / \mathrm{g}$ in pork, and finally, nd to $0.8161 \mu \mathrm{g} / \mathrm{g}$ in chicken.

The results were comparable to studies elsewhere between 1983 and 2006 [32-40] and clearly indicated that certain samples (P14 and Ch21) in the pork and chicken categories exceed the $\mathrm{Pb}$ MAL value $[40,41]$ and may pose a potential risk from $\mathrm{Pb}$ exposure when consumed.

Similarly, cadmium levels in canned meats have been analyzed and presented in Fig. 2. Once again, the results have been arranged in categories according to the type of meat studied

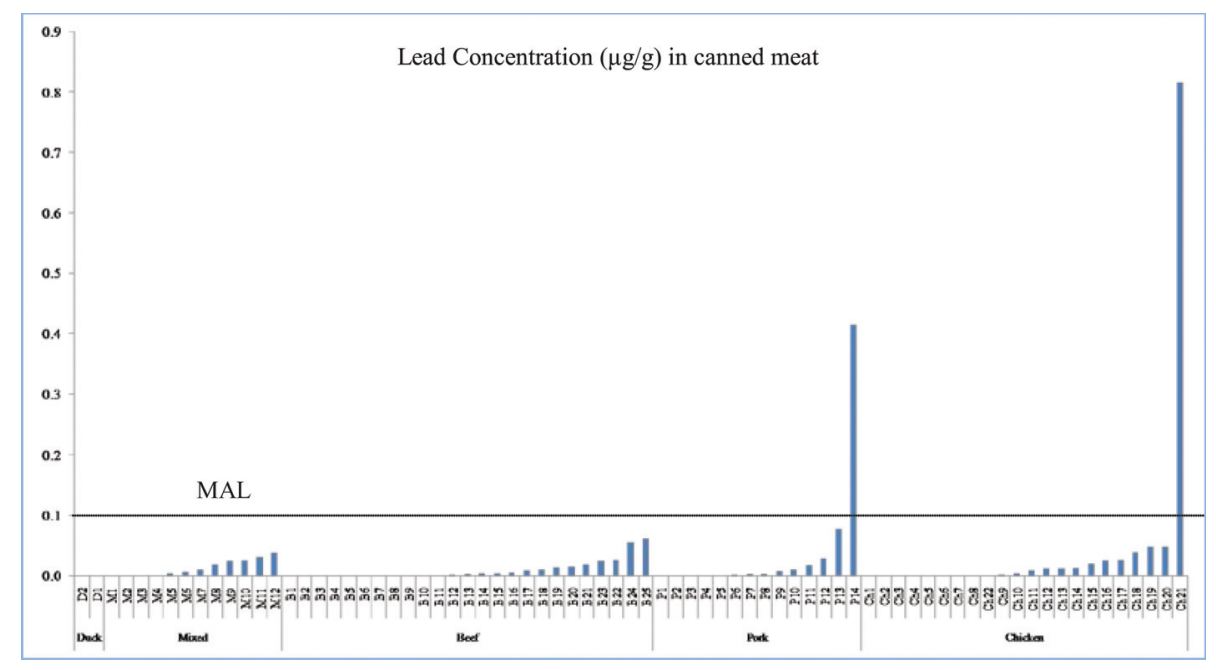

Figure 1: Lead concentration in canned meat of different categories. Concentrations of $\mathrm{Pb}$ are arranged from lowest to highest, within and between each category. Due to the high $\mathrm{Pb}$ concentration in Ch21 (0.8161 $\mu \mathrm{g} / \mathrm{g})$, concentrations below $0.0063 \mu \mathrm{g} / \mathrm{g}$ could not be observed. The maximum allowable level (MAL) of $\mathrm{Pb}$ in meat $(0.1 \mu \mathrm{g} / \mathrm{g})$ is also shown. 


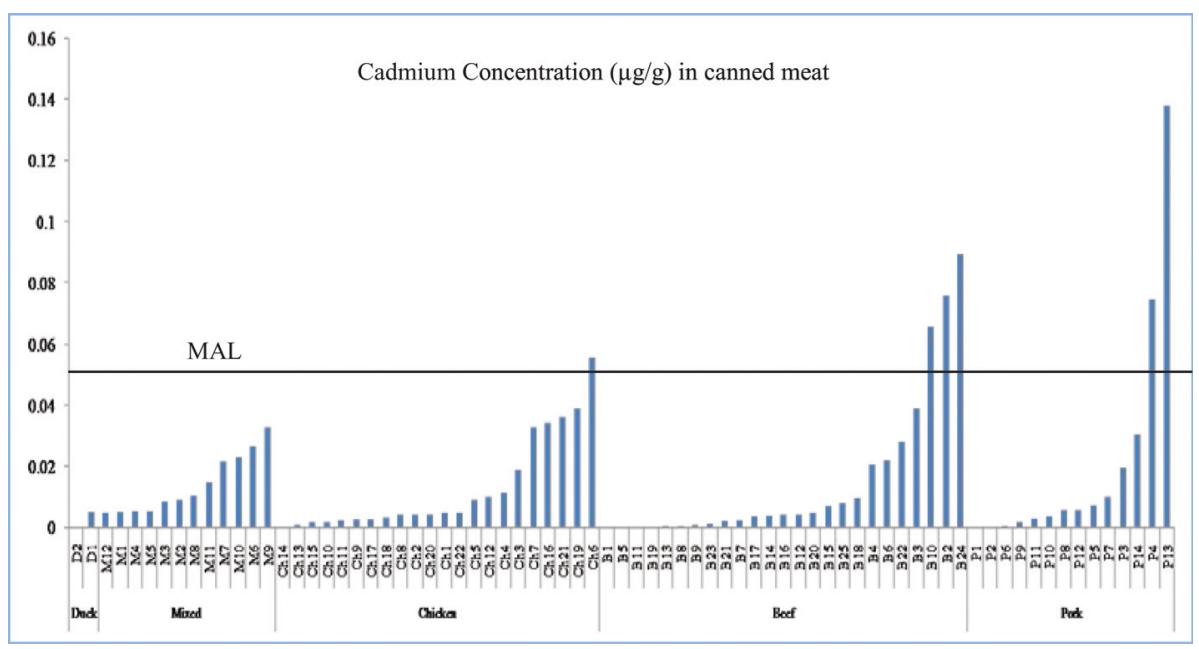

Figure 2: Cadmium concentration in canned meat of different categories. Concentrations of $\mathrm{Cd}$ are arranged from smallest to largest, between and within each category. Due to the high Cd concentration in P13 $(0.1382 \mu \mathrm{g} / \mathrm{g})$, concentrations below $0.0082 \mu \mathrm{g} / \mathrm{g}$ could not be observed. The maximum allowable level of $\mathrm{Cd}(0.050 \mu \mathrm{g} / \mathrm{g})$ is also shown.

and in increasing order of concentrations detected. All five types of canned meat contained various levels of cadmium where the concentrations ranged from nd to $0.00524 \mu \mathrm{g} / \mathrm{g}$ in duck, nd to $0.0327 \mu \mathrm{g} / \mathrm{g}$ in mixed, nd to $0.0558 \mu \mathrm{g} / \mathrm{g}$ in chicken, nd to $0.0893 \mu \mathrm{g} / \mathrm{g}$ in beef, and finally nd to $0.138 \mu \mathrm{g} / \mathrm{g}$ in pork. Similar to $\mathrm{Pb}$, it was clear that the consumption of certain brands (B24 and P13) of beef and pork may expose individuals to high Cd levels thus making them potential health hazards and of major concern. The MAL of Cd in meat with a set value of $0.05 \mu \mathrm{g} / \mathrm{g}$ was exceeded in six of the brands studied, namely Ch6, B2, 10 and 24, P4 and P13.

Based on data shown in Figs 1 and 2, Table 2 shows the amount of lead and cadmium intake per week for an average weight male, female and child while taking into account the highest concentrations analyzed in each studied category.

Since one of the ultimate goals of this study was to compare the estimated intake levels with PTWIs, it is crucial to stress that the PTWI represents the sum of intakes of a certain metal from all different sources whether dietary or not, and not specifically from meat alone. Knowing that the PTWI reference value for $\mathrm{Pb}$ is $0.025 \mu \mathrm{g} / \mathrm{g}$ bw [25], Table 2 indicates that with a normal weekly intake $(400-800 \mathrm{~g})$ of meat from the majority of the categories studied, the level of $\mathrm{Pb}$ contamination was still way less than the PTWI. However, the intake of $800 \mathrm{~g}$ of P14 alone or $400 \mathrm{~g}$ of $\mathrm{Ch} 21$ alone, by a 14-kg child leads to an estimated weekly intake of approximately $0.023 \mu \mathrm{g} / \mathrm{g}$ bw, which is almost equal to the PTWI (92\% of the PTWI).

The highest concentration of each category was used to calculate the amount of $\mathrm{Pb}$ and $\mathrm{Cd}$ intake based on consumption of 400 or $800 \mathrm{~g}$ of meat type studied. The highlighted values indicate brands that have closely reached or exceeded the PTWI of each metal.

Needless to say, that the consumption of $800 \mathrm{~g}$ of $\mathrm{Ch} 21$, which is still a reasonable amount of intake, shows that the PTWI was markedly exceeded in children whereby the estimated 
Table 2: Estimated weekly intake of $\mathrm{Pb}$ and $\mathrm{Cd}$ for canned meat.

\begin{tabular}{|c|c|c|c|c|c|c|}
\hline Metal & Category & $\begin{array}{l}\text { Highest } \\
\text { concentra- } \\
\text { tion }(\mu \mathrm{g} / \mathrm{g})\end{array}$ & $\begin{array}{l}\text { Estimated } \\
\text { weekly } \\
\text { intake(g) }\end{array}$ & $\begin{array}{l}\text { Weekly } \\
\text { intake }(70-\mathrm{kg} \\
\text { male) }(\mu \mathrm{g} / \mathrm{g} \\
\text { bw) }\end{array}$ & $\begin{array}{l}\text { Weekly } \\
\text { intake (60 } \\
\text { kg-female) } \\
(\mu \mathrm{g} / \mathrm{g} \text { bw) }\end{array}$ & $\begin{array}{l}\text { Weekly intake } \\
\text { (14 kg 2-years } \\
\text { old) ( } \mu \mathrm{g} / \mathrm{g} \mathrm{bw})\end{array}$ \\
\hline \multirow[t]{10}{*}{$\mathrm{Pb}$} & \multirow[t]{2}{*}{ Duck } & \multirow[t]{2}{*}{0} & 400 & 0 & 0 & 0 \\
\hline & & & 800 & 0 & 0 & 0 \\
\hline & \multirow{2}{*}{$\begin{array}{l}\text { Mixed } \\
\text { (M13) }\end{array}$} & \multirow[t]{2}{*}{0.0367} & 400 & 0.000210 & 0.000240 & 0.00104 \\
\hline & & & 800 & 0.000420 & 0.000490 & 0.00209 \\
\hline & \multirow[t]{2}{*}{ Beef (B25) } & \multirow[t]{2}{*}{0.0604} & 400 & 0.000350 & 0.000400 & 0.00173 \\
\hline & & & 800 & 0.000690 & 0.000810 & 0.00345 \\
\hline & \multirow[t]{2}{*}{ Pork (P14) } & \multirow[t]{2}{*}{0.414} & 400 & 0.002360 & 0.002760 & 0.01183 \\
\hline & & & 800 & 0.004730 & 0.005520 & 0.02365 \\
\hline & \multirow{2}{*}{$\begin{array}{r}\text { Chicken } \\
(\mathrm{Ch} 21)\end{array}$} & \multirow[t]{2}{*}{0.816} & 400 & 0.004660 & 0.005440 & 0.02332 \\
\hline & & & 800 & 0.009330 & 0.010880 & 0.04663 \\
\hline \multirow[t]{10}{*}{$\mathrm{Cd}$} & \multirow[t]{2}{*}{ Duck (D1) } & \multirow[t]{2}{*}{0.00524} & 400 & 0.000029 & 0.000035 & 0.00015 \\
\hline & & & 800 & 0.000059 & 0.000069 & 0.00029 \\
\hline & \multirow[t]{2}{*}{ Mixed (M9) } & \multirow[t]{2}{*}{0.0327} & 400 & 0.000190 & 0.000220 & 0.00093 \\
\hline & & & 800 & 0.000370 & 0.000440 & 0.00187 \\
\hline & \multirow{2}{*}{$\begin{array}{c}\text { Chicken } \\
\text { (Ch6) }\end{array}$} & \multirow[t]{2}{*}{0.0558} & 400 & 0.000320 & 0.000370 & 0.00159 \\
\hline & & & 800 & 0.000640 & 0.000740 & 0.00319 \\
\hline & \multirow[t]{2}{*}{ Beef (B24) } & \multirow[t]{2}{*}{0.0893} & 400 & 0.000510 & 0.000590 & 0.00255 \\
\hline & & & 800 & 0.001020 & 0.001190 & 0.00510 \\
\hline & \multirow[t]{2}{*}{ Pork (P13) } & \multirow[t]{2}{*}{0.138} & 400 & 0.000790 & 0.000920 & 0.00394 \\
\hline & & & 800 & 0.001570 & 0.001840 & 0.00788 \\
\hline
\end{tabular}

intake may reach $0.04663 \mu \mathrm{g} / \mathrm{g}$ of bw (186.5\% of the PTWI). Similarly, with a PTWI for Cd of $0.007 \mu \mathrm{g} / \mathrm{g}$ bw for all age groups [21], two meat samples were of concern especially for children. The consumption of $400 \mathrm{~g}$ of pork (P13) alone with a concentration of $0.138 \mu \mathrm{g} / \mathrm{g}$ has yielded an estimated weekly Cd intake of $0.00394 \mu \mathrm{g} / \mathrm{g}$ bw corresponding to $56 \%$ of the set PTWI. The consumption of $800 \mathrm{~g}$ instead has exceeded the set PTWI by $125 \%$ for children. Similarly, the consumption of $800 \mathrm{~g}$ beef (B24) alone under the same conditions caused $73 \%$ of the PTWI to be reached in children. Such observation suggests that awareness and regulation of consumption can play a powerful role in determining the risk of exposure to such toxic elements, especially after knowing that such toxic metals are present in our food chain.

The current situation presents a crucial stage where full awareness is required in the prevention of exposure to such health hazards especially that heavy metals first tend to bioaccumulate in the human body and second are taken from more than one source. In light of this, whether such products (canned and processed) are prepared locally or imported from elsewhere, it is crucial for the concerned authorities to place regulations for every step of the preparation procedure and before making the product available for consumers.

Figures 1 and 2 clearly show that there is no relationship between the presence of lead and cadmium within any given sample. In other words, samples that contained high levels of $\mathrm{Pb}$ 
are not necessarily high in $\mathrm{Cd}$, and vice versa. This may suggest once again that $\mathrm{Pb}$ and/or $\mathrm{Cd}$ contamination is not due to some constant factor such as the canning process alone, and that any such contamination might be due to the food, water intake, and other sources of environmental pollutions through which the animals have been exposed to during the bringing up process or during storage, processing and transportation.

In the processed meat brands, the levels of lead analyzed have been presented in Fig. 3 from lowest to highest concentrations under several categories. Based on the presented figure, the lowest $\mathrm{Pb}$ concentrations are exhibited in turkey samples (nd to $0.0266 \mu \mathrm{g} / \mathrm{g}$ ), followed by processed mixed (nd to $0.0543 \mu \mathrm{g} / \mathrm{g}$ ) while the highest $\mathrm{Pb}$ concentration were found in pork samples (nd to $0.0613 \mu \mathrm{g} / \mathrm{g}$ ). None of the samples have exceeded the MAL of Pb, nor have any shown to be a potential health hazard.

Cadmium was also analyzed in processed meats and the results have been presented in Fig. 4 in ascending order of concentrations detected. In the mixed category, the lowest detected level of $\mathrm{Cd}(0.000265 \mu \mathrm{g} / \mathrm{g})$ was found in $(\mathrm{C}+\mathrm{T}) 1$, while the highest $(0.00497 \mu \mathrm{g} / \mathrm{g})$ was found in $(\mathrm{C}+\mathrm{T}) 2$. For pork, the concentrations ranged from non-detectable $(\mathrm{P} 2, \mathrm{P} 5)$ to $0.0063 \mu \mathrm{g} / \mathrm{g}$ (P15) while Turkey samples ranged from $0.00118 \mu \mathrm{g} / \mathrm{g}$ (T3) to $0.0071 \mu \mathrm{g} / \mathrm{g}$ (T7).

Recalling that the PTWI for $\mathrm{Pb}$ is $0.025 \mu \mathrm{g} / \mathrm{g}$ of body weight, the calculations presented in Table 3 show that even with the consumption of $800 \mathrm{~g}$ of the highest contaminated pork sample (P18) by a 2-year-old child reveals a maximum estimated weekly intake of $0.0035 \mu \mathrm{g} / \mathrm{g}$ bw, which corresponds to $14 \%$ of the set PTWI. Similarly, for T7, with a Cd concentration of $0.0071 \mu \mathrm{g} / \mathrm{g}$, the consumption of $800 \mathrm{~g}$ by a 2 -year-old child will only yield $5.7 \%(0.4 \mu \mathrm{g} / \mathrm{g})$ of the PTWI $(0.007 \mu \mathrm{g} / \mathrm{g}$ bw). Accordingly, none of the samples measured in the processed meat category seemed to exhibit any high levels of lead based on the proposed estimated weekly consumption, and thus are considered to be much safer for consumption in comparison to those of the canned ones. Again, the results showed no relation between levels of $\mathrm{Pb}$ and $\mathrm{Cd}$, which may be due to the same reasons discussed earlier and are difficult to assess.

The highest concentration from each category was considered to calculate the amount of $\mathrm{Pb}$ intake based on consumption of 400 or $800 \mathrm{~g}$ of meat type studied.

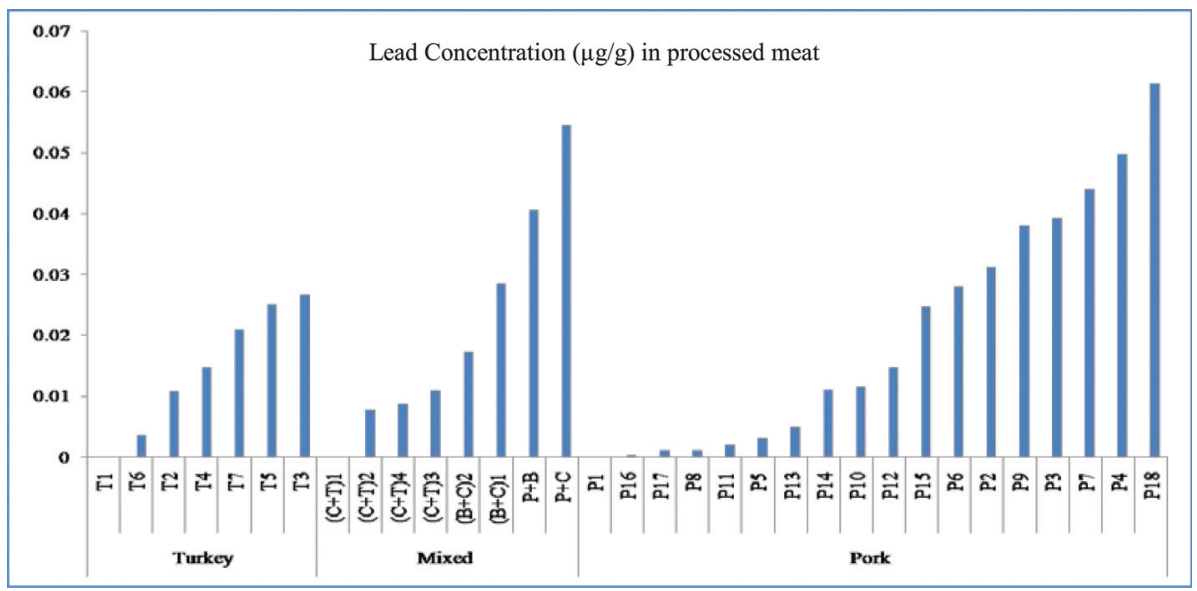

Figure 3: Lead concentration $(\mu \mathrm{g} / \mathrm{g})$ in processed meat $(\mathrm{T}$ : turkey, $\mathrm{P}$ : pork, $\mathrm{C}+\mathrm{T}$ : mixed chicken and turkey, $\mathrm{B}+\mathrm{C}$ : mixed beef and chicken, $\mathrm{P}+\mathrm{C}$ : mixed pork and chicken, and $\mathrm{P}+\mathrm{B}$ : mixed pork and beef). 


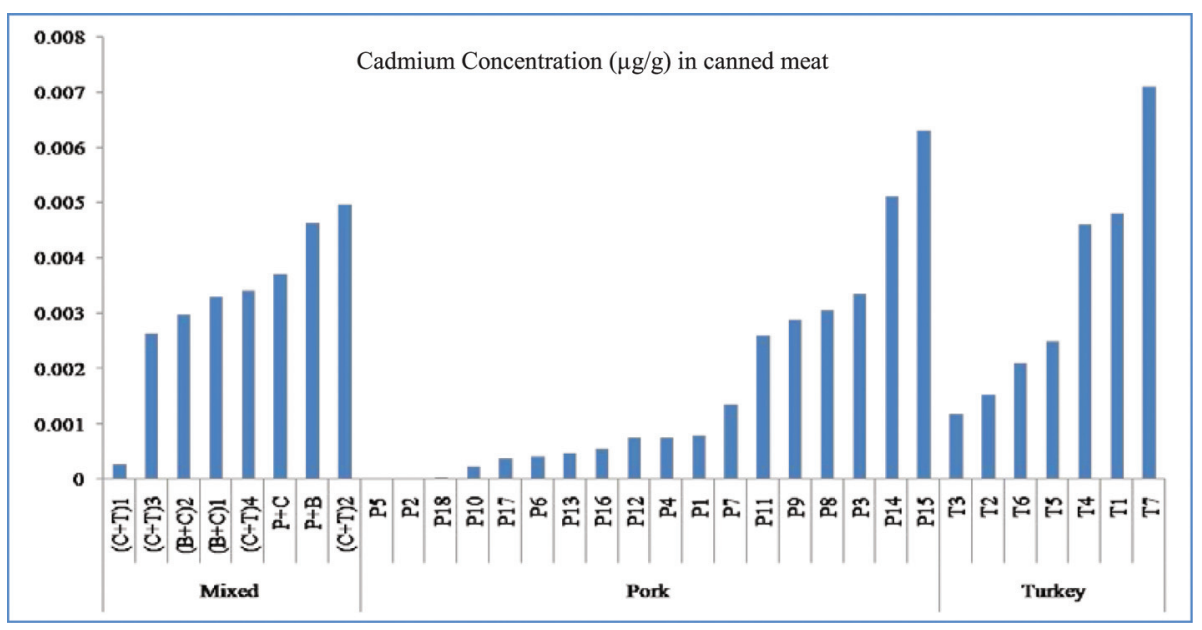

Figure 4: Cadmium concentrations $(\mu \mathrm{g} / \mathrm{g}$ ) in processed meat. The analyzed samples were arranged from lowest to highest $\mathrm{Cd}$ concentration within each category.

Table 3: Estimated weekly intake of $\mathrm{Pb}$ for processed meat.

\begin{tabular}{lclllll}
\hline \multicolumn{1}{c}{ Metal } & Meat type & $\begin{array}{l}\text { Highest } \\
\text { concentra- } \\
\text { tion }(\mu \mathrm{g} / \mathrm{g})\end{array}$ & $\begin{array}{l}\text { Estimated } \\
\text { weekly intake } \\
(\mathrm{g})\end{array}$ & $\begin{array}{l}70-\mathrm{kg} \text { male } \\
(\mu \mathrm{g} / \mathrm{g} \text { bw })\end{array}$ & $\begin{array}{l}\text { 60-kg female } \\
(\mu \mathrm{g} / \mathrm{g} \text { bw })\end{array}$ & $\begin{array}{l}\text { 14-kg 2-years } \\
\text { old }(\mu \mathrm{g} / \mathrm{g} \text { bw })\end{array}$ \\
\hline $\mathrm{Pb} \quad$ & Turkey & 0.0266 & 400 & 0.000150 & 0.000170 & 0.000760 \\
& $(\mathrm{~T} 3)$ & & 800 & 0.000300 & 0.000350 & 0.001520 \\
& Mixed & 0.0543 & 400 & 0.000310 & 0.000362 & 0.001550 \\
& (P+C) & & 800 & 0.000620 & 0.000720 & 0.003100 \\
& Pork (P18) & 0.0613 & 400 & 0.000350 & 0.000410 & 0.001750 \\
& & & 800 & 0.000700 & 0.000810 & 0.003500 \\
$\mathrm{Cd} \quad$ Mixed & 0.00497 & 400 & 0.000028 & 0.000033 & 0.000142 \\
& $(\mathrm{C}+\mathrm{T}) 2$ & & 800 & 0.000056 & 0.000066 & 0.000284 \\
& Pork (P15) & 0.0063 & 400 & 0.000036 & 0.000042 & 0.000180 \\
& & & 800 & 0.000072 & 0.000084 & 0.000360 \\
& Turkey & 0.0071 & 400 & 0.000040 & 0.000047 & 0.000200 \\
& $(\mathrm{~T} 7)$ & & 800 & 0.000081 & 0.000094 & 0.000400 \\
\hline
\end{tabular}

Lebanon is one of the countries that have recently been engaged in the process of performing total dietary studies (TDS) as a reply to the EFSA/FAO/WHO questionnaire on national TDS approach [42]. However, the conducted studies [27,43] are not enough to state whether a few or all of our samples can be considered as a potential health risk. Therefore, there is absolutely a great need for an international TDS procedure synchronization and application. Ultimately, and for this reason, one can consider that samples low or free of $\mathrm{Pb}$ and $\mathrm{Cd}$ can be considered the safest to consume, but nevertheless, this cannot be taken as a general rule since constant monitoring and screening is required prior to allowing the marketing of such products. According to the European Environment and Health Information system, most European countries had an adult $\mathrm{Pb}$ intake levels ranging between $10 \%$ and $30 \%$ of the lead's 
PTWI and sometimes higher [44]. It is not clear which TDS to follow as a guide since the study done in Lebanon does not agree with that of the European countries and is somehow surprisingly low perhaps due to non-comprehensive nature of the TDS carried. In addition, Lebanon is a developing country in which no environmental or health regulations exist, nor does it have any food safety monitoring programs but yet its $\mathrm{Pb}$ intake is somehow much lower (3.2\%) than that of the European countries (10-30\%). In the worst case and if one takes into consideration both TDSs, two canned brands (Ch21 and P14) can be considered unsafe for consumption specifically for children. If one considers the European TDS where $30 \%$ of the $\mathrm{Pb}$ PTWI has been reached from the diet (i.e. $0.0075 \mu \mathrm{g} / \mathrm{g}$ ), the remaining intake to reach $100 \%(17.5 \mu \mathrm{g} / \mathrm{g})$ will not only be reached by consuming $\mathrm{Ch} 21$ and P14, but can be markedly exceeded beyond the safe levels.

Regarding cadmium, its cadmium intake through the food chain in the Lebanese TDS is equal to $21.7 \%$ of the PTWI $(0.007 \mu \mathrm{g} / \mathrm{g} \mathrm{bw})$, which is much lower than the intake percentage found in Europe that ranges between $40 \%$ and $60 \%$. Taking into consideration both TDSs, only three canned brands (Ch6, B24, P13) may be considered unsafe for consumption especially for children. Taking into consideration the European TDS, Ch6, B24, and P13, are three brands that can compensate for the remaining amount in reaching $100 \%$ of the PTWI and perhaps higher. Therefore, such brands can also be considered to be unsafe for children.

Since the study shows that certain samples can be a real health hazard, it is therefore crucial for the concerned authorities to regulate such products on all levels by setting regulatory standards in order to manage and control such contaminants. In addition, fresh unprocessed samples should be also studied in the same region so as to compare with the current study and unleash any differences that might exist in the level of their contaminations.

\section{CONCLUSION}

The amount of research of toxic metal contamination in foodstuffs in Lebanon has not been given enough attention and only few reports exist within the last three decades. For this purpose, the contamination levels of $\mathrm{Pb}$ and $\mathrm{Cd}$ were assessed in meat products that are normally available to consumers all year round. The data provided extremely important information to whether or not Lebanese individuals are exposed to high levels of such toxic metals where specifically children were found to be more vulnerable to such exposures. Sixty-one percent of the analyzed brands of canned meat were found to have various levels of $\mathrm{Pb}$ contamination, while $91 \%$ showed Cd contamination. As for the processed, $91 \%$ exhibited various $\mathrm{Pb}$ concentrations, while $94 \%$ revealed the presence of $\mathrm{Cd}$. Of those samples, and specifically in the canned category, two brands have exceeded the MAL for $\mathrm{Pb}$ while six brands have exceeded the MAL for Cd. Regarding the processed category none of the samples have exceeded the MAL of either metal.

Two major parameters, amount consumed and body weight, were found to play an important role in determining whether the PTWIs of $\mathrm{Pb}$ and $\mathrm{Cd}$ were exceeded or not. Children were found to be the most vulnerable.

Overall, the results of this study (and similar studies) have demonstrated the presence of lead and cadmium contamination in the food chain. Knowing that such toxic metals tend to bioaccumulate and may be taken from more than one source present a crucial stage in reference to health hazards. Such observation necessitates the continuous monitoring for levels of toxic metals in food products. Food products must be labeled by official organizations to indicate the levels of heavy metals present. Awareness compaigns, from official or private organizations, are a must to help citizens choose safer products so as to minimize exposure risk to such toxic elements. 


\section{REFERENCES}

[1] Al-Chaarani, N., El-Nakat, J.H., Obeid, P.J. \& Aouad, S., Measurement of levels of heavy metals contamination in vegetables grown and sold in selected areas in Lebanon. Jordan Journal of Chemistry, 4(3), pp. 303-315, 2009.

[2] Järup, L., Hazards of heavy metal contamination. British Medical Bulletin, Department of Epidemiology and Public Health, Imperial College. 2003. doi: http://dx.doi. org/10.1093/bmb/ldg032

[3] Obeid, P.J., Saliba C., Younis M., Aouad S. \& El-Nakat J., Comparative analysis of lead and cadmium levels in various brands of canned and processed meat products in Lebanon. WIT Transactions on Ecology and the Environment, Vol. 170, WIT Press, 2013, ISSN 1743-3541, doi.10.2495/FENV 130131. doi: http://dx.doi.org/10.2495/fenv130131

[4] Muhammad, S., Tahir Shah, M. \& Khan, S., Health risk assessment of heavy metals and their source apportionment in drinking water of Kohistan region, northern Pakistan.Microchemical Journal, 98, pp. 334-343, 2011. doi: http://dx.doi.org/10.1016/j. microc.2011.03.003

[5] Dietz, R., Pacyna, J., Thomas, D.J., Asmund, G., Gordeev, V., Johansen, P., Kimstach, V., Lockhart, L., Pfirman, S.L., Rigét, F.F., Shaw, G., Wagemann, R. \& White, M., Heavy metals 1998. AMAP 1998. AMAP Assessment Report: Arctic Pollution Issues. Arctic Monitoring and Assessment Programme (AMAP): Oslo, Norway, pp. 373-524, 1998.

[6] Rahimi, E. \& Rokni, N., Measurement of cadmium residues in muscle, liver and kidney of cattle slaughtered in Isfahan abattoir using grafite furnace atomic absorption spectrometry (GFAAS): a preliminary study. Iranian Journal of Veterinary Research, $\mathbf{9 ( 2 ) ,}$ pp. 174-177, 2008.

[7] López Alonso, M., Benedito, J.L., Miranda, M., Castillo, C., Hernandez, J. \& Shore, R.F., Toxic and trace elements in liver, kidney and meat from cattle slaughtered in Galicia (NW Spain). Food Additives and Contaminants, 17(6), pp. 447-457, 2000. doi: http://dx.doi.org/10.1080/02652030050034028

[8] European Food Safety Authority (EFSA), Cadmium in food scientific opinion of the panel on contaminants in the food chain. European Food Safety Authority Journal, 980, pp. 1-139, 2009. doi: http://dx.doi.org/10.1108/nfs.2008.01738fab.020

[9] Health Canada, Draft Human Health State of the Science Report on Lead, available at http://www.hc-sc.gc.ca/ewhsemt/pubs/contaminants/ dhhssrl-rpecscepsh/index-eng. php (accessed September 2013)

[10] Winter-Sorkina, R., Bakker, M.I., Van Donkersgoed, V. \& Van Klaveren, J.D. Dietary Intake of heavy metals (cadmium, lead and mercury) by the Dutch population. (RIVM Rep.No.320103001). Center for Substances and Integrated Risk Assessment (SIR), National Institute of Public Health and the Environment (RIVM): Bilthoven, 2003.

[11] World Health Organization (WHO), Health risk of heavy metals from long-range transboundary air pollution. WHO: Copenhagen, 2007.

[12] Ministry for the Environment, Draft toxicological intake values for priority contaminants in soil. Wellington, New Zealand, 2010.

[13] National Science Foundation International (NSF). Dietary Supplement-standard 173, Metal Contaminate Acceptance Levels, available at http://pythonkit.com/DietarySupplement-Standard-173-Metal-Contaminant-Acceptance-Levels-downloadw8838.pdf (accessed September 2013)

[14] Mooney, M., FDA's Report: "Lead Found In Vitamins" Is Confusing, available at http:// www.michaelmooney.net/FDA's_Report_Lead_Found_In_Vitamins_Is_Confusing. pdf, 2003 (updated 5 July 2010). 
[15] Water UK, Cadmium, http://www.water.org.uk/static/files_archive/1Cadmium_Water_ UK.pdf

[16] World Health Organization (WHO), Preventing disease through healthy environments. Exposure to cadmium: a major public health concern. WHO: Geneva, Switzerland, 2010.

[17] Pacyna, J.M., Pacyna, E.G. \& Aas, W., Changes of emissions and atmospheric deposition of mercury, lead, and cadmium. Atmospheric Environment, 43, pp. 117-127, 2009. doi: http://dx.doi.org/10.1016/j.atmosenv.2008.09.066

[18] Darwish, T.M., Jomaa, I., Awad, M. \& Boumetri, R., Preliminary contamination hazard assessment of lead resources in central Bekaa plain of Lebanon. Lebanese Science Journal, 9(2), pp. 3-15, 2008.

[19] ICdA Europe, Cadmium Exposure and Human Health, available at http://www. cadmium.org/pg_n.php?id_menu=5\&ma_sql (accessed September 2013)

[20] Bull, S., Cadmium Toxicological Overview, available at http://www.hpa.org.uk/webc/ HPAwebFile/HPAweb_C/1194947375856, 2010.

[21] Consumer Product Safety Commission, Cadmium in Children's Medal Jewelry, available at http://www.cpsc.gov/library/foia/foia11/os/ cadmiumjewelry.pdf

[22] Demirezen, D. \& Uruc, K., Comparative study of trace elements in certain fish, meat and meat products. Meat Science, 74, 255-260, 2006. doi: http://dx.doi.org/10.1016/j. meatsci.2006.03.012

[23] Korfali, S. \& Abou Hamdan, W., Essentail and Toxic Metals in Lebanese Marketed Canned Food: Impact of Metal Cans. Journal of Food Research, 2(1), 2013, ISSN 19270887, E-ISSN 1927-0895 Published by Canadian Center of Science and Education, 2013. doi: http://dx.doi.org/10.5539/jfr.v2n1p19

[24] Obeid, P.J., El-Khoury, B., Burger, J., Aouad, S., Younis, M., Aoun, A. \& El-Nakat, J.H., Determination and assessment of total mercury levels in local, frozen and canned fish in Lebanon. Journal of Environmental Sciences, 23(9), pp. 1-6, 2011. doi: http://dx.doi. org/10.1016/s1001-0742(10)60546-3

[25] World Health Organisation (WHO), Lead. Safety Evaluation of Certain Food Additives and Contaminants. Fifty-third Meeting of the Joint FAO/WHO Expert Committee on Food Additives (JECFA), Geneva: WHO Food Additives Series, Vol. 44, pp. 273-312, 2000. doi: http://dx.doi.org/10.1016/s0168-1605(02)00160-5

[26] Al Othman, Z.A., Lead contamination in selected foods from Riyadh city market and estimation of the daily intake. Molecules, 15, pp. 7482-7497, 2010. doi: http://dx.doi. org/10.3390/molecules 15107482

[27] Nasreddine, L., Nashalian, O., Naja, F., Itani, L., Parent-Massin, D., NabhaniZeidan, M. \& Hwalla, N., Dietary exposure to essential and toxic trace elements from a Total diet study in an adult Lebanese urban population. Food and Chemical Toxicology, 48, pp. 1262-1269, 2010. doi: http://dx.doi.org/10.1016/j.fct.2010.02.020

[28] Knechtges, P.L., Food Safety: Theory and Practice, Jones \& Bartlett Publishers: USA, 2011.

[29] Badis, B., Rachid, Z. \& Esma, B., Levels of selected heavy metals in fresh meat from cattle, sheep, chicken and camel produced in Algeria. Annual Research and Review in Biology, 4(8), pp. 1260-1267, 2014. doi: http://dx.doi.org/10.9734/arrb/2014/7430

[30] Abdolgader, R.A., Hussain, R.A., Hasan, S.M. \& Agoub, A.A., Quantitative determination of $\mathrm{Cd}$ and $\mathrm{Pb}$ in Tissues and Organs of Chickens Raised in El-Jabel Alakhder Region-Libya. Food and Nutrition Sciences, 4, pp. 763-766, 2013. doi: http://dx.doi. org/10.4236/fns.2013.48098 
[31] Alturiqi, A.S. \& Albedair, L.A., Evaluation of Some Heavy Metals in Certain Fish, Meat, and Meat Products in Saudi Arabian Markets. Egyptian Journal of Aquatic Research, 38, pp. 45-49, 2012. doi: http://dx.doi.org/10.1016/j.ejar.2012.08.003

[32] Dabeka, R.W. \& McKenzie, A., Total diet study of lead and cadmium in food composites: preliminary investigations. Journal of the Association of Official Analytical Chemists, 75(3), pp. 386-394, 1992.

[33] Karavoltsos, S., Sakellari, A., Dimopoulos, M., Dasenakis, M. \& Scoullos M., Cadmium content in foodstuffs from Greek market. Food Additives and Contaminants, 19(10), pp. 954-962, 2002. doi: http://dx.doi.org/10.1080/02652030210136973

[34] Onianwa, P.C., Lawal, J.A., Ogunkeye, A.A., \& Orejimi, B.M., Cadmium and nickel composition of Nigerian foods. Journal of Food Composition and Analysis, 13(6), pp. 961-969, 2000. doi: http://dx.doi.org/10.1006/jfca.2000.0944

[35] Cervera, M.L., Modificaciones del cotenido en cadmio, cobre, plomo y cinc en los procesos de elaboración de jamón cocido y pasta de hígado. Revista de Agroquímica y Tecnología de los Alimentos, 28(2), pp. 233-240, 1988.

[36] Becerra, G., Burguera, J.L. \& Buguera, M., Determination of lead and cadmium in foods samples by flow-injection atomic absorption spectrometry. Química Analítica, 6, pp. 52-59, 1987.

[37] Catalá, R., Montoro, E. \& Ibáñez, N., Contaminación por metales pesados de los productos cárnicos. Revista de Agroquímica y Tecnología de los Alimentos, 23(2), pp. 202-216, 1983.

[38] Cattaneo, P. \& Balzaretti, C., Livelli attuallidi piombo e cadmio negli alimenti., 23, pp. 771-780, 1984.

[39] Brito, G., Díaz, C., Galindo, L., Hardisson, A., Santiago, D. \& Montelongo G.F., Levels of metals in canned meat products: Intermetallic correlations. Bulletin of Environmental Contamination and Toxicology, 44(2), pp. 309-316, 2005. doi: http://dx.doi. org/10.1007/bf01700152

[40] Meah, M.N., Lead and tin in canned foods: results of the UK survey 1983-1987. Food Additives and Contaminants, 8(4), pp. 485-496, 1991. doi: http://dx.doi.org/10.1080/ 02652039109373999

[41] Dailos, G-W., Karlsson, L., Caballero, A., et al., Lead and Cadmium in meat products consumed by a Spanish population (Tenerife Island, Spain). Journal of Food Additives and Contaminants, 23(8), pp. 757-763, 2006. doi: http://dx.doi. org/10.1080/02652030600758142

[42] WHO, State of the art on total diet studies based on the replies to the EFSA/FAO/WHO questionnaire on national total diet study approaches. European Food Safety Authority (EFSA), Food and Agriculture Organization of the United Nations (FAO), \& World Health Organization (WHO), available at http://www.efsa.europa.eu/en/supporting/ doc/206e.pdf, 2011.

[43] Nasreddine, L., Hwalla, N., El Samad, O., LeBlanc, J.C., Hamzé, M., Sibiril, Y. \& ParentMassin, D., Dietary exposure to lead, cadmium, mercury and radionuclides of an adult urban population in Lebanon: A total diet study approach. Food Additives and Contaminants, 23(6), pp. 579-590, 2006. doi: http://dx.doi.org/10.1080/02652030500529452

[44] European Environment and Health Information System (ENHIS), Exposure of children to potentially hazardous chemicals in food, avaialble at http://www.euro.who. int/_data/assets/pdf_file/0004/97042/4.4.-Exposure-of-children-to-chemical-hazardsin-food-EDITED_layouted.pdf, 2009. 